\title{
Assessing the Lead Market Potential of Countries for Innovation Projects
}

\author{
Marian Beise ${ }^{\mathrm{a}}$ and Thomas Cleff ${ }^{\mathrm{b}}$ \\ ${ }^{\text {a }}$ Centre for European Economic Research (ZEW), Mannheim, Germany, \\ Research Institute for Economics and Business Administration, Kobe University, 2-1 Nada ku, \\ Rokkodai, Kobe-shi, Email: rian@ @rieb.kobe-u.ac.jp \\ ${ }^{\mathrm{b}}$ Pforzheim University of Applied Sciences, Pforzheim, Germany \\ Running Title: Assessing Lead Market Potential
}

\begin{abstract}
This paper presents an approach to assessing the potential of countries to increase the likelihood that locally preferred innovation designs become successful in other countries, too. The concept suggests that for many innovations lead markets exist that initiate the international diffusion of a specific design of an innovation. Once a specific innovation design has been adopted by users in the lead market chances are that it subsequently becomes adopted by users in other countries as well. Lead markets can be utilised for the development of global innovation designs. By focusing on the design of the innovation which responds to the preferences within the lead market, a company can leverage the success experienced in the lead market for global market launch. In order to follow a lead market strategy of new product development, it is necessary to assess the lead market potential of countries before an innovation is developed and tested in the market. This paper presents an indicator-based methodology that approximates the lead market attributes of countries. This assessment methodology was applied to two innovation projects at the truck division of DaimlerChrysler AG. The method produces information that is of importance for the development phase and the market launch of globally standardised innovations.
\end{abstract}

Key Words: Innovation, Global Diffusion, Market Entry 


\section{Introduction}

When Siemens, a large electrical machinery and office equipment manufacturer headquartered in Germany, analysed the market opportunity for the new facsimile technology in the 1970s they concluded that neither an introduction in Europe nor in the biggest foreign market, the United States, would be successful. The prototype machines were bulky and emitted an awful scent; the paper was physically irritating and the quality of the transmitted text was poor. The telex system, which was already popular in some local markets, seemed more advantageous. The marketing team of the telecommunications division at Siemens, however, discovered that Japan preferred the facsimile technology because of the pictorial character of its language and thus held a lead market advantage over Europe and the United States that threatened Siemens' global market position in the text-based telecommunications equipment sector. They concluded that once the technological design of text-based telecommunications equipment opens up a mass market in Japan, it would develop the power to spread worldwide and squeeze designs preferred in other countries out of the world market. As a result, the telecommunications division of Siemens did not abandon facsimile technology but introduced a fax machine in Japan. The Japanese affiliate of Siemens took the responsibility for further development of the technology as well as for the market launch, documented the market feedback and constantly refined the product. As expected, the fax machine was not only a big success in Japan. When the mass market emerged and the diffusion of the fax machine took off in 1985 , production costs decreased rapidly due to economies-of-scale of production. Lower prices and improved quality made the fax machine become increasingly popular in the United States and Europe as well. As a result of the pioneer advantage in Japan, Siemens became the leading producer of fax machines.

As most readers will know, the strategic response of Siemens to the situation in the 1970s described here is fiction. What is true is that at that time Siemens had developed a 
considerable technological advantage in facsimile technology. Unfortunately, it did not carry out an analysis on the lead market potential of countries. Because of low market response from the German market, they abandoned facsimile technology and concentrated R\&D activities on improving the telex system. In contrast, Japanese firms sensing local demand for the particular technology invested continuously in facsimile technology and introduced a stream of improved fax machines in Japan. The resulting bandwagon spread over to the United States and later to Europe. The international diffusion of the fax machine rendered Japanese manufacturers, such as NEC, Ricoh and Sharp, dominant. At the end of the 1980s, Japanese firms nearly controlled $90 \%$ of the world market (Yoffie 1997, p. 33). The facsimile technology eventually superseded the telex system, which had been the preferred device in Europe and the US.

Countries where users prefer and adopt a specific innovation design that does not only appeal to domestic users, but can subsequently be successfully commercialised in other countries as well, can be called lead markets, countries that follow lag markets. Lead market countries are a chance for firms to develop global innovations. By concentrating attention and resources on one country market, focusing on a narrow range of market preferences and feedback, a firm can lower the market research costs as well as speed up the process of innovation development. In knowing the market context of the lead market it can avoid nationally idiosyncratic innovation designs. Firms that do not respond to lead markets run the risk that their innovation designs albeit initially successful in their home markets become squeezed out of the market by innovation designs adopted in the lead market.

The lead market approach to global innovation strategy of international firms was first suggested in the 1980s by Porter (1986) and has been discussed since then (e.g., Gerybadze et al. 1997, Johansson 2000). Bartlett and Ghoshal (1990) describe lead markets are "the markets that provide the stimuli for most global products and processes of a multinational 
company" (Bartlett and Ghoshal 1990, p. 243). Yet, the term 'lead market' has been used in various ways in literature in the past. In the definition used by most diffusion researchers a lead market is a country in which the diffusion process of an innovation first takes off (e.g. Kalish et al, 1995, Kotabe, Helsen 1998). Other authors have used the term 'lead market' to denote the country in which an innovation was invented (Yip 1992), in which a subsidiary of a multinational company takes over global product responsibility, for instance as global coordinator of marketing activities (Raffée, Kreutzer 1989), or as a mixture of all (Jeannet 1986).

We define lead markets as regional markets with specific attributes that increase the probability that a locally preferred innovation design becomes internationally successful as well. ${ }^{1}$ After studying many globally successful innovations, such as cellular mobile telephony, the fax machine, personal computer and others, we argue that in order to contribute to strategic innovation management of a firm lead markets should be defined solely by market context factors of countries and not by firm specific factors or scientific technological knowledge endowments of countries. For most global innovations we analysed, the early adaptation in one country was the stimulating factor that led to the international competitiveness of firms that responded to the country market. First of all, there rarely was a significant general scientific-technological knowledge gap between firms in the US, Europe and Japan. If a knowledge gap existed, it was either closed quickly by firms that perceived a stronger local market demand than firms in other countries or it concerned technological nuances that often result from different local conditions and preferences. Most firms and even international corporations are biased towards their home market environment. Home market conditions such as demand preferences and environmental conditions often shape a firm's innovations. Local infrastructure and complementary goods or the lack thereof influence the design of a product; the creativity of engineers is stimulated by their own living context while 
market knowledge is perceived and acquired most conveniently from the home market with information from foreign markets being less weighted or understood than information from the home market. The technological capacity of firms is then used to match local conditions that often cause the resulting new products and processes to be culture specific. The Japanese preference for the fax machine is one example. The personal computer has been described as a response to the call for independence by the individualistic American society. The perfection of an air conditioning system in a car is of little interest to users in countries with mild climate. The benefit of a technology is not general; it is commonly environment-specific. Therefore, in addition of looking for the "best" technology, it is necessary for an international firm to analyse the ability of countries to make nationally preferred innovations beneficial and adopted in foreign markets.

In this paper, we present a method of assessing the potential of countries to leverage a national innovation success internationally. The lead market analysis suggested here aims at assessing the lead market potential of countries for a specific innovation project. After retrieving that information, the firm can decide on how to respond to the lead market potential of a foreign country according to its own firm-specific capabilities and global resource allocation. In this manuscript, we suggest an analytic method to assess the lead market potential of countries for specific innovation projects.

We first review the different mechanisms that can be responsible for the international diffusion of an innovation design that is first adopted in a single country and the emergence of a globally dominant design. We argue that several country-specific characteristics exist, that increase the probability that a design preferred domestically becomes the globally dominant design. These attributes can be arranged in a set of five groups, the lead market factors. To identify potential lead markets we have developed a concept of lead markets that focuses on quantifying lead market factors. In the second stage, we report on the procedure and the 
results of a real application of our methods to estimate the potential lead market role of countries for two innovation projects of the truck division of DaimlerChrysler AG.

\section{Origins of the Lead Market Role of Countries}

\subsection{The International Diffusion of Innovations}

Since countries have different preferences and reap different benefits from innovations (or the innovation has different price tags from country to country) they prefer different innovations. While the diversity from country to country initially induces a variety of nationally preferred innovations, an innovation often emerges as globally successful. Figure 1 exhibits the typical international diffusion pattern of a specific innovation.

Figure 1: The international diffusion pattern of an innovation design

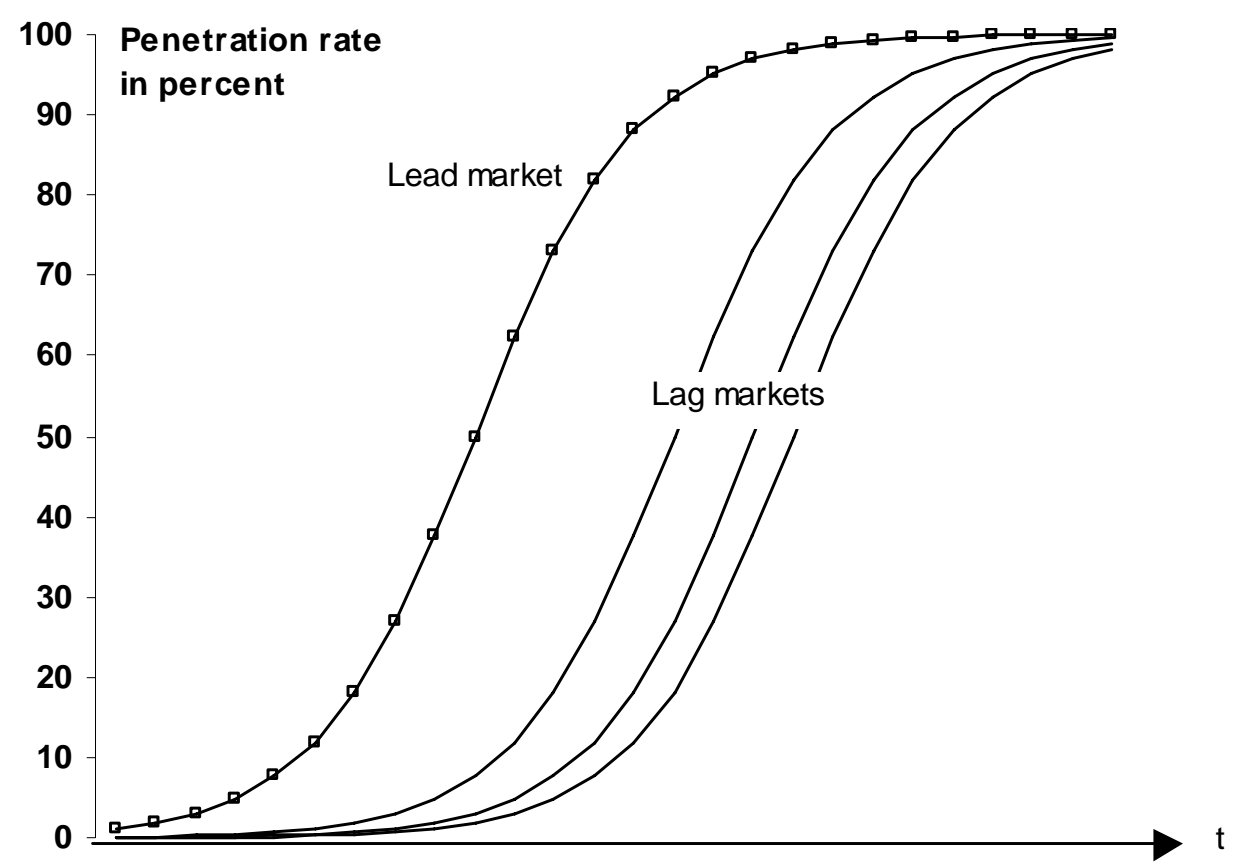

Starting with Griliches (1957) this pattern of the diffusion of an innovation across regions and countries is frequently observed. The first studies on the international diffusion of innovations are by Maddala and Knight (1967) and Poznanski (1983) about steel making processes, by Swan (1973) studying the adoption of synthetic rubber, Nasbeth and Ray (1974) reviewing 
the diffusion of production techniques and Antonelli's (1986) study on information technologies. One of the most detailed studies to date is Tilton (1971). More recently Gatignon et al. (1989), Dekimpe et al. (1998a/b), Takada, Jain (1991), Ganesh et al. (1997) have added analysis on the order of countries adopting a specific innovation. All these studies found evidence for a variety of factors why technology diffuses from country to country. It has been observed that the lead market is often not the country where the innovation was invented or where the technology used for it was mainly developed.

Before discussing the factors of international diffusion, a defining aspect of the lead market phenomenon has to be emphasized. Lead markets have previously been characterised as having the most innovative customers, i.e. customers who are most open to new products, most willing to adopt early and risk the failure of an innovation (e.g. Albach 1993). Takeuchi and Porter (1986) as well as Johansson and Roehl (1994) define lead markets as markets with the most demanding buyers or those buyers most likely to adopt innovations anticipating a continuous flow of new products incorporating state of the art technology. In contrast, a closer look at the situation in the first phase of the diffusion process reveals that, often, it is not the innovativeness of users that explains the time lag between countries, but that different designs of the same innovation idea were initially preferred from country to country. These different designs compete worldwide and one finally emerges as the global dominant design while the other designs vanish from the market place. An innovation design, as defined by Utterback (1994), is a specification or configuration of an innovation idea. Different designs of an innovation have the same basic function but different specifications or a different mix of attributes such as size, quality performance, precision, technology, energy consumption etc. Different designs are characterised as alternatives for the same need or function and therefore compete against each other on the world market. For instance, the fax machine is an 
innovation design of a communication device transmitting written information. An IBM and an Apple computer are different designs of a personal computer. ${ }^{2}$

Figure 2 includes the diffusion curves of competing innovation designs that were initially adopted by a lag country that switched to the lead market design. This pattern illustrates that lead markets are not necessarily the most innovative markets. The telex system was adopted before the fax machine hit the markets. In France, an online service similar to the Internet was adopted widely in the early 1980s that let other countries cool, before the Internet took off in the United States ensuing a world buzz. Countries, which quickly adopt an innovation design that is never adopted by other countries, can be called idiosyncratically innovative markets. A firm responding to idiosyncratic markets can gain a temporary local innovation success but is later compelled to switch to the dominant design losing its pioneer advantages. To the contrary, firms responding to the market conditions of the lead market can internationally leverage local knowledge which they have preferred access to through their home market advantage (Linder 1961) sustained by the experience curve and other pioneer advantages. Since the lead country normally stays ahead in the penetration rate over a long period of time, they constantly benefit form early user feedback representative for the world market enabling them to constantly adjust the design to the mass market needs ahead of their global competitors. 
Figure 2: The international diffusion pattern of competing innovation designs

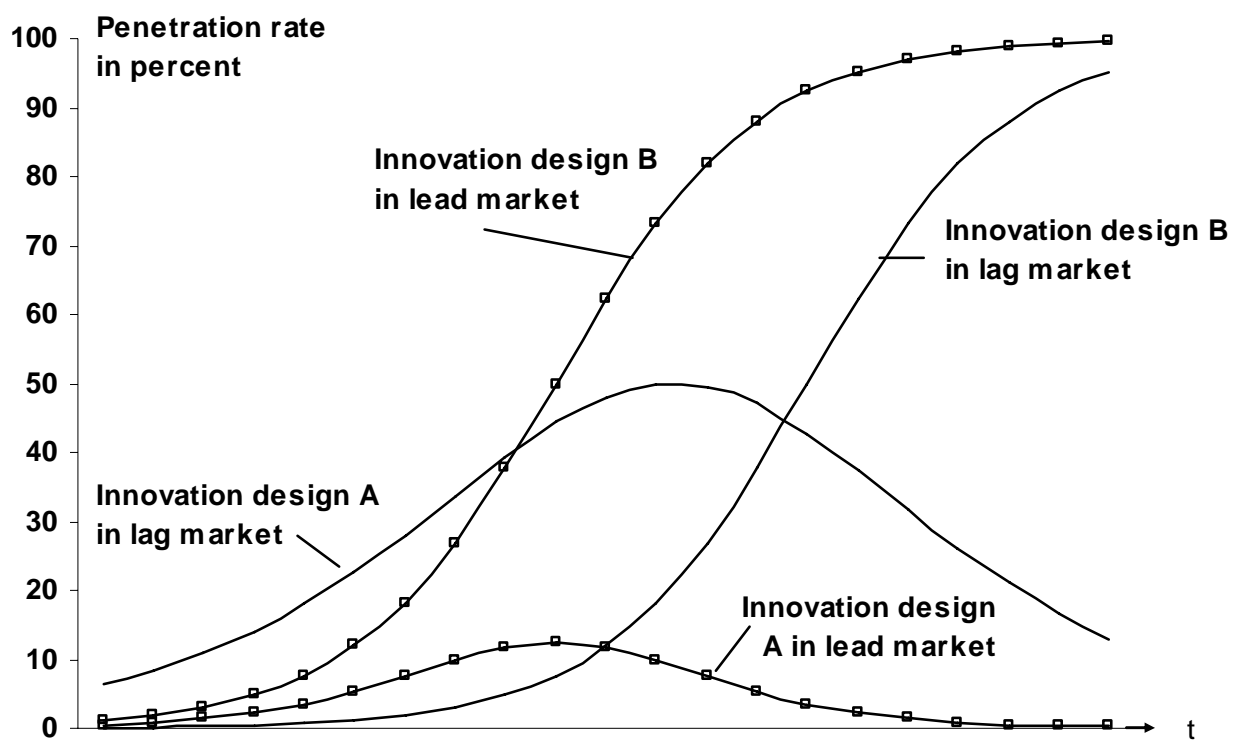

The preferences of a country are not always so easy to explain like in case of the fax machine. However, this is not the main question, since it is more relevant to explain why other countries follow and the innovation design that sells in the lead market is able squeeze out designs previously preferred in other countries. The more important question is why other countries follow the lead market. In the next section, we present a simple consumption model that demonstrates various internationalisation mechanisms.

\subsection{A Simple Theoretical Model of Lead Markets}

We start with a simply two product two country, two stage static comparative consumption model to find out what drives a country to adjusts its consumption patter towards that of another country. Let us consider two countries that in the first stage favour different product designs, meaning that each product design has a large market share in one country and a low one in the other. Either the two designs represent an innovation confronting an established product that the innovation aims to replace or they represent two different designs of an innovation. The latter case describes two nation-specific innovation designs competing to become the globally dominant design. The former is the more commonly referred case of an 
innovation introduced in the world market. It is assumed though that both countries have the same general willingness to adopt innovations, so that the different consumption pattern results from different market contexts. Within the economic theory of consumer behaviour (e.g. Deaton, Muellbauer 1980), different consumption patterns in countries can be the result of (1) different budget constraints, (2) different preferences, i.e. different properties of goods are preferred because of varying environmental context or tastes, and (3) different prices of the goods in the two countries.

In the second stage both countries prefer the innovation design that was preferred initially by one country, which at this time can be called the lead market. There are three general reasons for the other country to change its adoption pattern: (1) the available budget of users reach levels that was present in the lead market in the first stage, (2) the relative benefit of the product adopted in the lead market for users in the lag country could have increased, and (3) the relative price of the product in the lag country could have decreased.

Interpreting these changes of adoption stimuli, three basic lead market mechanisms can be derived. First, the lead market experiences anticipatory demand. Anticipatory demand means that the lead market enjoys a budget or yields a high relative benefit of an innovation design that later is available for users in other countries as well. The international trend of increasing average income causes a superior product to be adopted earlier in markets with high-income levels (Vernon 1966, Dekimpe et al. 2000). A country also renders anticipatory demand that is at the forefront of an international trend that changes the utility of specific innovations. This is what Porter (1990) calls a demand advantage of a country and how Bartlett and Ghoshal (1990, p. 243) explain lead markets: "local innovation in such markets becomes useful elsewhere as the environmental characteristics that stimulated such innovations diffuse to other locations". 
Second, preferences in the lag market can be influenced by consumer choices of users in the lead market. For instance, adoption reduces uncertainty about the benefit of an innovation design. This "demonstration effect" has often been considered an important mechanism of diffusion (Mansfield 1968, Kalish et al. 1995). Potential adopters in a lag country observe the success of the innovation in the lead market, triggering a high adoption rate in the lag country. Reputable first adopters of an innovation signalling the credibility of an innovation can further reduce the risk of adoption.

And third, a relative price reduction of the design preferred in the lead market for users in the lag market shifts consumption in the lag market away from the previously preferred design towards the design preferred in the lead market. This price mechanism can be further divided into two sub cases. The price of the lead market design is initially lower in the lead market than in the other market, but the lower price becomes available over time in the other country as well (anticipatory price conditions). Second, if prices are the same but preferences differ in from country to country, an innovation design becomes adopted by both countries if the price of the design preferred in the lead market decreases in relation to the prices of other designs. This price reduction effect is the main argument of Levitt's (1983) famous "globalisation of markets" hypothesis. It describes a simple substitution effect: innovation designs that become less expensive become dominant in countries that would prefer other innovation designs.

Relaxing two assumptions of the consumption model, perfect information on consumer preferences and non-strategic behaviour of firms and consumers, leads to two additional arguments for the internationalisation of innovation pattern. First, when preferences are not perfectly known, companies test the market with alternative innovation designs. The more alternatives offered the higher the likelihood of finding the technological design that is the most beneficial and the larger the variety of new applications of an innovation. Differences in the competitive climate in countries can lead to different consumption patterns even if 
preferences and process are the same. For instance, in a country with a monopolist fewer alternative designs are offered than in a country where several companies compete. The argument for the internationalisation is that fierce competition in one country may lead to the discovery of an innovation design that is more beneficial for users in other countries than the best among the locally offered designs. Thus the initial consumption pattern of the lag markets does not reflect the local preferences when too few alternatives are offered in the market to uncover the preferences and determine the locally most beneficial design. A country with more local competitors or tougher competition is therefore more likely to find a design that is the most beneficial to both itself and many other countries as well.

Second, if companies or customers or other actors in the market (suppliers, banks, government) expect the other country to be the lead market they could strategically bias the innovation designs offered locally towards the preference system of the other country. It can be expected that a design would have a better chance of becoming the globally dominant design if it matches the preferences of the other country and already incorporates features that enhance its utility there.

In order to apply these fundamental theoretical arguments to a specific innovation project, a system of five basic groups of lead advantages of a country has been derived: demand advantages, price advantages, transfer advantages market structure advantages and export advantages. All national advantages and the relevance of the specific topics within each category are innovation specific. While this section should give the theoretical background, the next section shall provide a roadmap for the derivation of variables in order to quantify the lead market potential of countries for specific innovation designs. 


\section{An Applied System of Lead Market Advantages of Countries}

\subsection{Demand advantage}

Central to this internationalisation mechanism is a global trend in which specific innovations become increasingly beneficial or preferable in most countries. In the past, the dominant global trend that explained a lead market was increasing income (Vernon 1966). Today, however, per capita income does not vary much among industrialised countries. The relevant trends nowadays are, for instance, demographic trends, environmental trends or socioeconomic trends. An international trend can also be in the build-up of infrastructure complementary to innovations (streets, distribution system, refuelling stations) or the availability of complementary goods (video cassettes). The demand advantage is rather exogenous, meaning that the global trend occurs independent of the adoption decision of the lead market.

Lead markets share this feature of the demand advantage with lead users suggested by von Hippel (1986). A trend is also the main diffusion mechanism that prompts other users to follow the lead users. Lead users are users who "face needs that will be general in the marketplace - but face them months or years before the bulk of that marketplace encounters them" (von Hippel 1986, p. 786). Behind that, von Hippel suggests, lays a trends of environmental conditions or technology as the diffusion mechanism.

\subsection{Price advantage}

A continuous decline in the relative price of one innovation design was the most frequent means to overcome international demand differences in the cases we studied before. The price of fax machines, the cellular mobile phone and the personal computer dropped considerably faster than their respective competing designs. For instance, the cost of production of the fax machine was reduced thirty-fold from 1980 to 1992 (Coopersmith 1993). Relative price 
reductions are mostly based on economies of scale of mass production thus giving the country with the biggest market for an innovation a cost advantage. Large countries therefore have a cost advantage but the total population does not always determine the size of the market. For specialised high-tech products with few applications, small countries can also offer a sufficiently large domestic market (Kravis, Lipsey, 1971). In addition to size, market growth can have an effect on costs. The cost of a new technology is higher for the potential adopter if existing production techniques have to be replaced than if new capacity has to be deployed. In addition, faster growth will lower the risk of producers having to make full use of new investments (Porter 1990).

Another cost advantage can result from staying at the forefront of an international trend in factor prices, such as input factors for the production or complementary factors for the utilisation of a specific product, such as petrol for a car or video cassettes for a video recorder. The cost advantage can result from increasing or decreasing factor prices. First, an innovation of universal appeal is normally adopted to a greater extent in a country where it first costs less. In the cellular mobile telephone industry, prices of calls decreased steadily worldwide after the introduction of the mobile phone in the early 1980s. In Nordic countries, this global price trend was anticipated since prices were already at low levels in the 1980s. Second, a cost advantage can result from increasing factor costs when rising factor prices induce factor saving innovations that initially are country-specific but later meet global market needs. For example, a country where labour costs are at such high levels that machinery companies concentrate their innovation efforts on automating machinery will be a lead market if labour costs in other countries follow the upward trend relative to the cost of other factors.

\subsection{Transfer advantage}

Innovations can internationally diffuse when the adoption behaviour of customers of foreign markets is influenced by the adoption of an innovation design in the lead market. The 
adoption of one innovation design in one country increases the perceived benefit of an innovation design in another country because it lowers the uncertainty associated with an innovation (demonstration effect). Information on the innovation not only enhances the awareness of the innovation design but also reduces the uncertainty surrounding new products and processes. International diffusion of durable goods thus depends on the intensity of communication between two countries (Takada, Jain, 1991). Putsis et al. (1997) show that the number of cross-border communication ties is not equally distributed among nations and is not symmetrical. A case study included in Nabseth and Ray (1974, p. 115) demonstrates that users get information on innovations of a product domain from preferred countries. The reputation and sophistication of a user in one country can be a signal for the quality of an innovation design for users in other countries. Another transfer advantage previously noted by Porter (1990) and Douglas and Wind (1987) is when the preference of a country for a design can be actively transferred abroad, e.g. by businesspersons, military and tourists. This transfer effect can stem from multinational companies as well. They have an incentive to use standardised equipment in all subsidiaries, which creates demand for foreign innovation designs.

Network externalities can also increase the benefit of an innovation design across countries, making an innovation adopted abroad more attractive for users than the indigenous design. The worldwide success of the Internet could have been based on this effect. Countries that used different online protocols, such as France, slowly switched from the home-grown system to the Internet. However, while externalities often drive the diffusion of a dominant design within a country (Varian 2001), squeezing out local innovation designs in foreign countries necessitates cross-country externality overcompensating for local externalities within a foreign country. This requires strong interaction between actors of different countries. For 
instance, the number of fax machine users in Japan did not increase the benefit of the fax in the US since communication between America and Japan is limited.

\subsection{Market structure advantage}

Competition and entrepreneurial effort have been described as two of the main determinants of international patterns of adoption of innovations from Posner (1961) to Dosi et al. (1990). A lead market is a competitive market. First of all, industrial customers tend to be more demanding towards their suppliers when they face competition than when they are tightly regulated or hold a monopoly (Porter 1990). Second, competing firms are more strongly pressured to follow those who have already adopted a new technology (Mansfield 1968, p. 144). And third, maybe most importantly, more innovation designs are tested in a competitive market than in a monopolised market. As a result, a competitive market is more apt to find a design that is not only the best within the domestic environment but also the best across all national environments. Fierce domestic competition facilitates finding an internationally homogenous latent consumer demand for innovations. Competition was indeed found to be a national competitive advantage (e.g. Porter 1990, Mowery 1995, Sakakibara, Porter 2001). The degree of competition can be measured with market concentration indicators, firm formation activities indicating barriers of entry or fluctuations in market share (Sakakibara, Porter 2001)

\subsection{Export advantage}

Three factors can deliver an export advantage: the similarity of local market conditions to foreign market conditions, domestic demand that is sensitive to the problems and needs of foreign countries, and local agents that put pressure on companies to develop exportable products. In the first place, innovations are easier to export if the environment and market conditions of foreign countries are similar to those of the domestic market the innovation was designed for. Dekimpe et al. (1998b) support the hypothesis already suggested by Vernon 
(1979) that the closer the similarity of cultural, social and economic factors between two countries, the greater the likelihood that an innovation design adopted by one of two countries will be adopted by the other country as well. A country is more likely to resort to a foreign design if the loss of benefit is small. That gives a country whose innovation-specific attributes of the environment lays in the middle of the range of environmental conditions an export advantage over countries with somewhat more extreme environmental conditions.

Even if the domestic environment is not at the forefront of a global trend, a high sensitivity of domestic users to global problems can push domestic companies into a global perspective and increase their ability to meet global problems before companies in other countries. For instance, consumers in one country can be sensitive to the effects of worldwide climatic change even if their domestic environment is not affected as much as that of other countries. Other examples are wildlife protection, wood cutting in the tropics and pollution caused by raw material extraction.

Pressure for export can come from local users, suppliers, financial sources and other national institutions. Some customers put pressure on producers to develop globally successful and not idiosyncratic solutions if they can expect lower prices for an innovation that can be exported, even if the idiosyncratic version would technically suit their own environment better. The argument of export orientation is similar to what Ohmae (1995) calls a "port of entry": a region or state that is shaped by the demands of the global economy and characterised by large export shares. A strong export orientation of local companies shapes the political, social and cultural system of a nation, the education of its engineers and managers, the export competence of employment and its supporting institutions (governmental agencies).

Export orientation however is difficult to measure exogenous, because export shares are also the result of a lead market role that might be derived from factors other than export orientation. 


\section{Assessing the lead market potential}

\subsection{The estimation model}

The lead market concept presented here is based on the assumption that the country with the largest lead market advantages as described above is most likely to become the lead market. The lead market potential of countries can be estimated by quantifying the lead market advantages for a particular innovation idea. Yet, because historical accidents play a role in the lead market pattern as well, one cannot totally predict the lead market. The method suggested is an indicator-based international benchmark using indicators that approximate the countryspecific lead attributes derived from the basic theoretical internationalisation mechanisms.

No variables in the theoretical model can be observed directly. They have to be quantified with proxies. Figure 3 depicts both the structural model of the lead market theory and the two empirical models that assign empirical data to theoretical constructs. The structural model is the theoretical relationship between country specific advantages and the lead market potential. The empirical models construct indicators that correlate strongly with the latent variables. On the left side, appropriate indicators for the lead market factors have to be collected for each innovation project for every regional market that could be a lead market. 
Figure 3: Structural and empirical models of the lead-market analysis

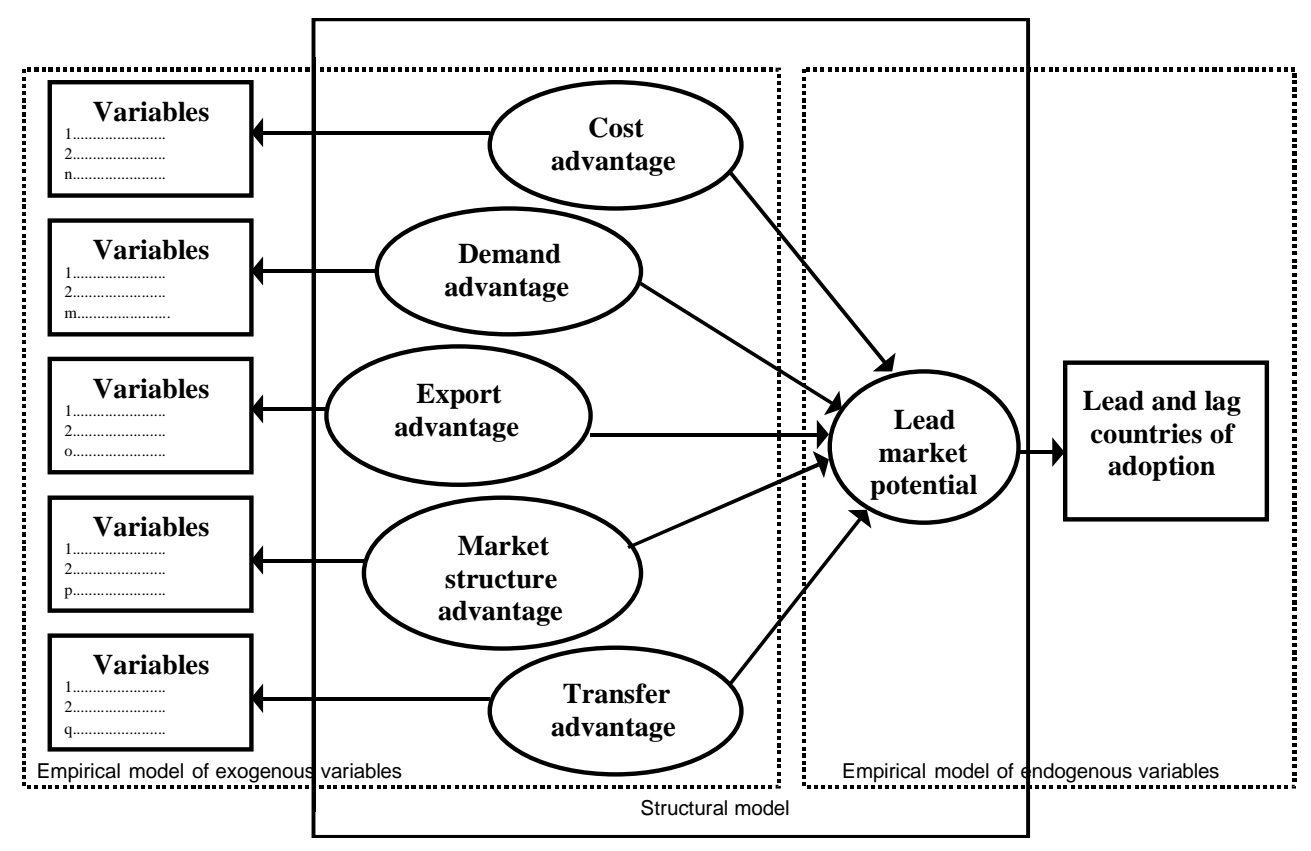

The lead market factors are all relative variables and not absolute variables, because the lead market potential results from the relative advantage of one country compared to other countries. Although lead markets could be countries, sub-national regions or groups of countries, the examples of internationally as well as nationally successful innovations suggest that the country level is the most common. In relation to the lead market advantages, countries tend to be more homogenous within their own boundaries and more heterogeneous in relation to other countries, and externalities that support standardisation are mostly local (see e.g. the seminal work by Hägerstrand 1973). In addition, it is difficult to acquire data on a subnational level. An aggregation of the quantified lead market factors would provide us with a measure for the lead market potential of a firm.

The application of the lead market model ends with the derivation of estimates for the lead market potential. The right side of the model would provide us with an empirical outcome that would allow to check the prediction power of the lead market potential. However, testing the prediction requires collecting a sufficient number of ex post facto lead market cases. The reason for this is the observation pattern of lead markets. It can only be observed whether a 
country is a lead market or a lag market. There is no further distinction within lag markets, whether they followed earlier or later. For example, the observation of the exogenous variable would be 1 for the lead market and 0 for all countries that follow. In the current situation, one must make an analysis of potential lead markets for innovation ideas without information on the real contribution of each lead market factor. This aggregation problem is discussed further below.

The suggested estimation method was applied in an exploratory study for the truck division of DaimlerChrysler AG. The aim was to identify potential lead markets based on the lead market method for two ongoing innovation projects. The truck industry is characterised by a variety of market contexts inhibiting the emergence of globally standardised models. As a result of internationally varying legal requirements, driving conditions, fuel prices, quality norms and driving habits, designs of trucks used in the United States, Europe and Asia vary considerably in many aspects. Few parts are interchangeable and few are globally standardised. However, for globally standardised innovations such as the GPS global positioning system, the antilocking brake and $\mathrm{CB}$ radio, the lead market pattern of the international diffusion can be observed.

In two ongoing innovation projects, the lead market advantage had to be estimated for various countries in order to check whether a single country holds a global advantage enabling it to push a locally preferred innovation design to become the global dominant design. For both innovation projects, the lead market concept seemed to be highly relevant, as the next section will show.

\subsection{Two innovation projects}

The first innovation project is the development of a system that automates a standard truck or lorry. An automated vehicle guidance (AVG) system would have to control all tasks of a driver so that the driver could be totally substituted. Specialised automated vehicles have been 
used before in ports and manufacturing facilities for repetitive transport tasks. However, these automated guided vehicles have been specially designed for a particular context. An automated standard truck on the other hand would have many advantages. It could be employed in a wide range of locations and in the public vicinity, for instance in a convoy of trucks on public highways. It could be guided both automatically and manually, for instance automatically within a container port and manually when driving outside. And because of standardisation they would be cheaper than specialised work trucks.

The team of engineers that was assigned to develop the system would first face the task of selecting the appropriate technology from within a variety of alternatives. Vehicles can be guided with a variety of technologies such as GPS, laser or other optical positioning systems, radio communication, transponder and wires embedded in the road. Automated guided trucks can be either controlled by a central control unit or equipped with visual sensors to be able to drive in a previously unknown area. The choice of technology would depend on the country, which the system would be primarily designated for, because of different infrastructures, legislations, and driving contexts from country to country. In some countries, for instance there is already some telecommunication devices employed along public highways; that could be used for automated vehicle guidance.

According to the project team and other sources, such as the Japanese Technology Evaluation Centre (JTEC 1993), there is no technological gap between Japan, the USA and Europe in the field of AGVs. This would mean that each county or region would be able to come up with a technically sophisticated solution to the innovation task most likely to be best fitted to each regions context. On the other hand, standardisation advantages are present. An electronic guidance system would have an extensive cost reduction potential if mass produced. The creation of an infrastructure necessary to guide vehicles on public roads bears network externalities making the extra equipment of a standard truck more beneficial for users that can 
occasionally use automated driving as cruise control. Given the increasing commercial cross border traffic, network effects would be international advocating international standardisation. Furthermore, the risk of liability for personal injuries associated with automated vehicles on public roads implies that a proven technology will be more accepted than unproven technologies leading to a lock-in effect. As a result, if automated guided trucks are to become widely used in the future, there are forces that push towards a globally dominant technology even if the design of the trucks themselves remains internationally diverse.

The second innovation project is the development of a remote diagnosis system (RDS) for modern trucks. The main problem of new high-tech trucks today is that specialised diagnosis equipment is often necessary to repair them. One solution would be to remotely support the repair of a truck either by detecting defects of the truck when a breakdown occurred, communicating with the driver to enable him to repair the truck himself or preparing a mobile maintenance service to bring the appropriate spare parts, to the defective truck. Another alternative would be to concentrate the online support on service points that are not equipped with the latest diagnosis technology.

The engineering team initially envisioned highly sophisticated three dimensional goggles that would allow an expert at the central service station to see what the driver sees and guide the driver to carry out some diagnosis and repair tasks. The communication would have been realised through cellular telephony, satellite-based telephony or on a fixed-line basis. After the lead market analysis was prepared, the design was changed considerably adapting it to the context of the potential lead market.

A lead market for this innovation can be expected as well. Since the market context, previous adoption of an IT-based diagnosis services, the demand for new uses of telecommunication and the existing IT infrastructure differs internationally in terms of availability and price, it is likely that countries would initially prefer different technological designs. Yet, automation 
and navigation systems, as well as the different modes of IT diagnosis and repair services, are likely to converge into worldwide standards when price reductions occur, as most IT developments have previously shown.

\subsection{The Situation at the DaimlerChrysler Truck Division}

Since its merger with Chrysler and the acquisition of Fuso, the truck division of Mitsubishi Motors of Japan, DaimlerChrysler trucks is more committed to developing innovations that could subsequently be commercialised worldwide. For both innovation projects, however, it was seen as crucial to achieve an early success in one country or region in order to get the financial resources necessary for the global market entry.

Traditionally most of the new technologies used in new Mercedes-Benz trucks were first introduced into the German market. The home market was naturally seen as the springboard to foreign markets because of its large size, sophisticated customers and the knowledge of Mercedes engineers and sales staff. The European market in particular is characterised by an increasing complexity of motor technology in commercial vehicles. The American and Asian truck markets appear to be less prepared to adopt new technologies and service features. User know-how of new truck technologies was considered as being less sophisticated than in Western European markets. Germany, however, is rather a lag market for services. Users tend to adopt technology-based service innovations such as distribution systems and services offered in banks later than in other countries. Services make up a smaller share of industry here than in other countries. The project teams therefore presumed that Germany would not be the best market to enter first with its telecommunications-based service innovations.

What made the choice critical is that the prime target market would determine the technology used because countries vary in their telecommunications infrastructure and both innovations would use the telecommunications infrastructure somehow. To maximise the benefit for local users, the design of the new service would have to use the infrastructure available in the 
market, which the service would be predominantly designed for. Europe offers a dense network of cellular mobile services in which even less populated rural areas benefit from extensive coverage. Large parts of the United States and Australia in contrast are still not covered by cellular telephony and are only accessible via satellite.

Both project teams were aware of their global resources, the backing of the upper management that would enable them to select the country market to enter first freely. The lead market concept follows exactly this strategy: design an innovation to suit demand in a single country to achieve a first market success and later leverage the lead market potential of the country and introduce the innovations with the same technology in other countries as well. The innovation project teams were therefore receptive to our proposal to use these innovation projects as a first real case for assessing the lead market potential.

\subsection{Collecting indicators for lead market factors}

The main practical challenge of the empirical model of the exogenous variables is to find national data on indicators that can be used as proxies for the lead market factors. Table 1 gives an overview of the set of variables used for the five lead market factors in the case of the remote diagnosis service (RDS). The first column lists the main lead market factors and their sub factors as described before. In the second column, variables are specified to quantify the lead factor for the specific innovation project. It was compiled during discussions with the project teams. The variables are either directly country-specific, such as factor costs prevailing in a country, or they are attributes of the technical design of an innovation preferred by the country, such as the cost reduction potential of the design.

Since the variables in the second column are derived without concern of data availability ("ideal"), variables had to be found for which national data is available and which would correlate with these ideal variables. The third column lists the indicators that are expected to be good proxies for the lead market advantages of countries. For instance, the degree of 
competition in country is indicated by concentration of truck sales in the country market. The Herfindahl index was used to quantify the concentration degree. Altogether a set of 32 and 29 indicators respectively was used in the analysis. National data was found in a variety of databases published by international organisations such as the OECD, IMF, World Bank or United Nations. However, some indicators were not available. In these cases, even weaker proxies have been used. For instance, the GDP per capita was used as a variable for income of customers. Other variables were derived by interviewing experts, ${ }^{3}$ for example the know how of the users. For some variables, no appropriate data could be found at all.

A group of 44 countries for the remote diagnosis innovation and 30 for the automated guided truck was included in the analysis. These groups consist of all OECD countries and those nonOECD countries which were deemed by the project team members as being relevant as possible lead markets. Even if some countries seem odd, company people often have expectations about the lead markets and if these countries are not included in the analysis, they later might fail to give full support to the strategy.

The estimation of the cost reduction potential of designs is normally too difficult or costly for a lead market analysis. In our project, we assume the same cost reduction potential of different designs and take various estimates for the national market size as the main proxy for the price effect. For the demand effect and the anticipatory factor price effect trends have to be identified. After the trend is specified, the country that leads the trend has to be assigned the largest value of a trend variable. For instance, a decreasing factor price trend means that the country with the lowest factor price is the country with the highest lead effect: the prices must therefore be transformed into negative values. The main trend for the innovation projects are identified as the trend toward automation $(\mathrm{AGV})$ and the trend of call center services (RDS). Variables for the demand advantage are always relative measures, such as penetration 
rates or income per capita, to denote the rank of countries on a trend regardless of their market size. 
Table 1: : A system of variables as proxies for lead market factors for a specific innovation project

\begin{tabular}{|c|c|c|}
\hline Innovation: & Remote diagnosis service for trucks & Preliminaries \\
\hline NACE industry class.: & 64.20 .3 or $64.20 .5(50.20 .1)$ & Competing technologies: maintenance service stations \\
\hline Potential markets & $\begin{array}{l}\text { Australia, South Africa, China, } \\
\text { Scandinavia, Brazil }\end{array}$ & $\begin{array}{l}\text { Former experience, failures: good market response for services in } \\
\text { UK, emergency radio signal button for sedans sells best in USA }\end{array}$ \\
\hline Lead market factors & Variables & $\begin{array}{l}\text { Available indicators as proxy } \\
{[\mathrm{M}] \text { etric, }[\mathrm{O}] \mathrm{rdinal},[\mathrm{N}] \mathrm{ominal} \text { (standardised) }}\end{array}$ \\
\hline \multicolumn{3}{|l|}{ Cost advantage } \\
\hline Price reduction potential & $\begin{array}{l}\text { Cost decline per production volume and } \\
\text { accumulated production volume }\end{array}$ & $\begin{array}{l}\text { [M] Market size (trucks) } \\
\text { [M] Market growth (trucks) } \\
\text { [M] Number of call centre seats } 1999 \\
\text { [M] Predicted number of call centre seats } 2005 \\
\text { [M] Absolute growth rate of call centre seats } \\
\text { [M] Annual average of telecom revenue between } 1995 \text { and } 1997\end{array}$ \\
\hline Market growth & Growth of sales of transportation services & $\begin{array}{l}\text { [M] Road, inland surface goods transported (million hauled tkm) } \\
\text { [M] Total road expenditure: annual average between } 1993 \text { and } \\
1996 \text { [in SDR] }\end{array}$ \\
\hline Anticipatory factor costs & Cost of telecommunication service & $\begin{array}{l}\text { [M] Average of the total road user taxation/road network }(\mathrm{km}) \\
\text { [M] Cost of 3-minute local call in } 1995 \text { [in US\$] } \\
\text { [M] Cellular, cost of 3-minute call in } 1995 \text { [in US\$] }\end{array}$ \\
\hline \multicolumn{3}{|l|}{ Demand advantage } \\
\hline \multirow[t]{2}{*}{ Trend } & Demand for telesupport services per user & $\begin{array}{l}\text { [M] Call centre seats per capita (1999) } \\
\text { [M] Share of call centre seats with at least one service in } 2005 \\
\text { [M] Share of service/GDP (1993) }\end{array}$ \\
\hline & $\begin{array}{l}\text { Demand for mobile telecomm. services } \\
\text { per capita }\end{array}$ & [M] Cellular mobile telephone subscribers per capita \\
\hline Income & $\begin{array}{l}\text { Average income of road haulage } \\
\text { companies as a share of revenue }\end{array}$ & $\begin{array}{l}\text { [M] Annual Average of the GDP per capita between } 1993 \text { and } \\
1997 \text {, PPP }\end{array}$ \\
\hline Collateral assets & Road infrastructure density & {$[\mathrm{M}]$ Density of total road network $(\mathrm{km} / \mathrm{km} 2)$} \\
\hline User know-how & $\begin{array}{l}\text { Innovation expenditure of road haulage } \\
\text { companies } \\
\text { Quality of trucks used }\end{array}$ & $\begin{array}{l}{[\mathrm{O}] \text { Know-how of road haulage companies }} \\
{[\mathrm{M}] \text { Unit value for truck 5-20 tonnes }} \\
{[\mathrm{M}] \text { Unit value for truck }>20 \text { tonnes }}\end{array}$ \\
\hline \multicolumn{3}{|l|}{ Export advantage } \\
\hline Sensibility to global needs & Sensibility for remote support of trucks & $\begin{array}{l}\text { [M] Annual average of injury accidents between } 1993 \text { and } 1997 \\
\text { per Capita }\end{array}$ \\
\hline Export orientation & $\begin{array}{l}\text { Export intensity for trucks and mobile } \\
\text { equipment }\end{array}$ & $\begin{array}{l}\text { [M] Murder, volume of crime per } 1000000 \text { people (1996) } \\
\text { [M] Trade balance of trucks [5-20 tonnes] } \\
\text { [M] Trade balance of trucks [>20 tonnes] } \\
\text { [M] trade balance of mobile phones } \\
{[\mathrm{M}] \text { Trade Balance of videophones }}\end{array}$ \\
\hline $\begin{array}{l}\text { Similarity to foreign } \\
\text { markets }\end{array}$ & Language compatibility & $\begin{array}{l}{[\mathrm{M}] \text { Share of international citizens speaking the same official }} \\
\text { language }\end{array}$ \\
\hline \multicolumn{3}{|l|}{$\begin{array}{l}\text { Market structure } \\
\text { advantage }\end{array}$} \\
\hline Competition & $\begin{array}{l}\text { Market power (price-cost/cost ) } \\
\text { Market concentration }\end{array}$ & $\begin{array}{l}\text { [O] Competition of road haulage companies } \\
\text { [M] Productivity of the telecom sector between } 1995 \text { and } 1997 \\
\text { [M] Competition trucks (1/Herfindahl index) }\end{array}$ \\
\hline Contestability & Market entry costs & Not available \\
\hline Firm formation & New firms to number of existing firms & Not available \\
\hline \multicolumn{3}{|l|}{ Transfer advantage } \\
\hline Risk & $\begin{array}{l}\text { International reputation of road haulage } \\
\text { companies }\end{array}$ & Not available \\
\hline Multinational firms & $\begin{array}{l}\text { Share of worldwide revenues of firms } \\
\text { headquartered in the country }\end{array}$ & $\begin{array}{l}{[\mathrm{M}] \text { Production share of domestic firms abroad }} \\
{[\mathrm{O}] \text { Share of international road haulage companies }}\end{array}$ \\
\hline $\begin{array}{l}\text { International mobility of } \\
\text { users }\end{array}$ & $\begin{array}{l}\text { Share of foreign revenues of road haulage } \\
\text { companies }\end{array}$ & $\begin{array}{l}\text { [M] Annual average of transport services [\% of total service } \\
\text { exports] }\end{array}$ \\
\hline International attention & $\begin{array}{l}\text { Share of worldwide reports on road } \\
\text { haulage subjects }\end{array}$ & Not available \\
\hline Government influence & $\begin{array}{l}\text { Share of governmental subsidies to total } \\
\text { investments of road haulage companies }\end{array}$ & Not available \\
\hline
\end{tabular}

For the export advantage, export shares and the export import ratios of products that relate to the innovations have been used. In the RDS case the crime rate was included as an indicator for the sensibility of local customers for the global value of the service, since the project 
manager considered the perception of a threat for an idle truck along the road as a main motive of buyers. In the category of market similarity, the usage of the local language abroad is an indicator for international compatibility in the RDS case.

The transfer advantage was the most difficult to quantify with the exception of the reach of multinational firms in the truck industry and the haulage firms. The other categories of the transfer advantages such as reputation of countries had to be assessed by polling experts, which we did only for the haulage firms' competence measure as a proxy of sophistication of users in the demand advantage section.

\subsection{Aggregating the indicators}

In order to derive a ranking of countries in terms of the lead market potential the set of quantified lead market factors must be aggregated. The aggregation is carried out in two steps. First, the set of variables for each lead market factor is reduced using a main component analysis. ${ }^{4}$ This process leads to a small set of standardised measures for lead market factors, meaning that their mean is 0 and their standard derivation is 1 leaving the skewness of the distribution as the information they carry. In the second step, we derive a single value for the lead market potential, simply using the arithmetic average of the main components or other simple aggregation means.

In the RDS case, the main component factor analysis results in the reduction of 34 variables into two main components for each lead market advantage. The assignment of the indicators to the main components is shown in Table 2. The two components of the price advantage can be interpreted as a size and a cost component. The demand advantage can be reduced to usage of tele-services and user expertise. The price advantage was reduced to the components market size and anticipatory factor costs. The demand advantage could be specified as the demand for the use of telecommunications-related services on the one hand and the availability of collateral assets and user expertise on the other. The export performance of 
countries in trucks and communications equipment and the compound of similarity and sensibility indicators finally indicate the export advantage. The market structure advantage goes back to competition in the telecoms sector and competition in the truck market. Finally, the transfer advantage is represented by indicators for the activities of multinational firms and by the single indicator for the mobility of users.

Table 2: Assignment of different items to the components of the main component analysis

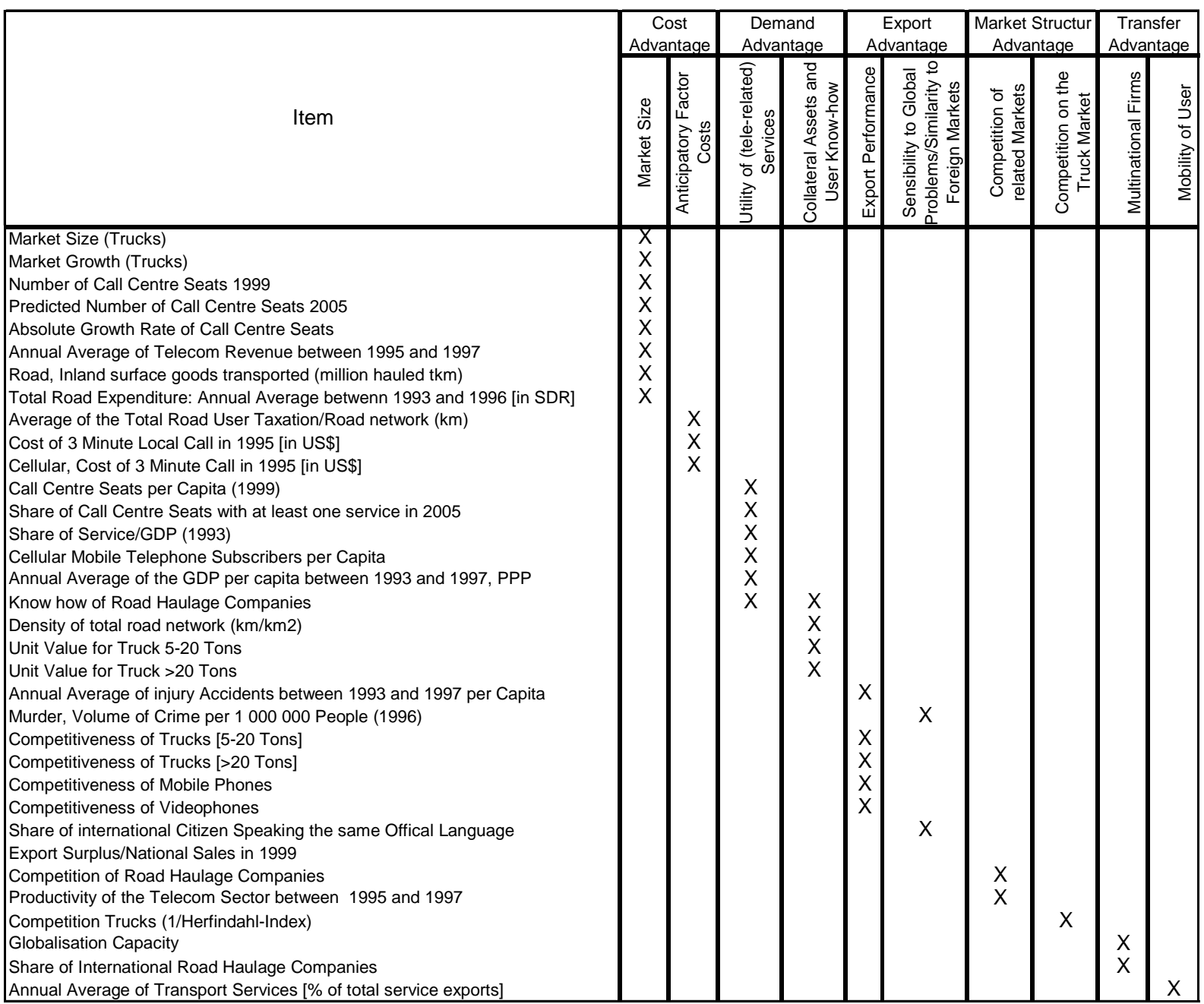

As a result, a matrix of ten main components for 30 countries was generated, which was presented to the project teams and discussed leaving room for discussions about the importance of each advantage. To reduce the set of lead market components to a country ranking, the values of the components were amalgamated into indices for each country by different methods. Several country-ranking methods are used to test for robustness of the 
result against the ranking method: the mean of all component values, the mean without the biggest value of each county, the mean without the size component, the median, the number of top 10 rankings of a country for each component, and the number of last 10 rankings. Figure 3 depicts the values of the twelve countries with the largest lead market potential for a remote diagnosis system for several aggregation methods. In most cases, the USA hold a strong lead in the lead market potential, suggesting that for this innovation a lead market pattern is to be expected starting in the US.

\section{Figure 3: Ranking of potential lead markets with different ranking methods}

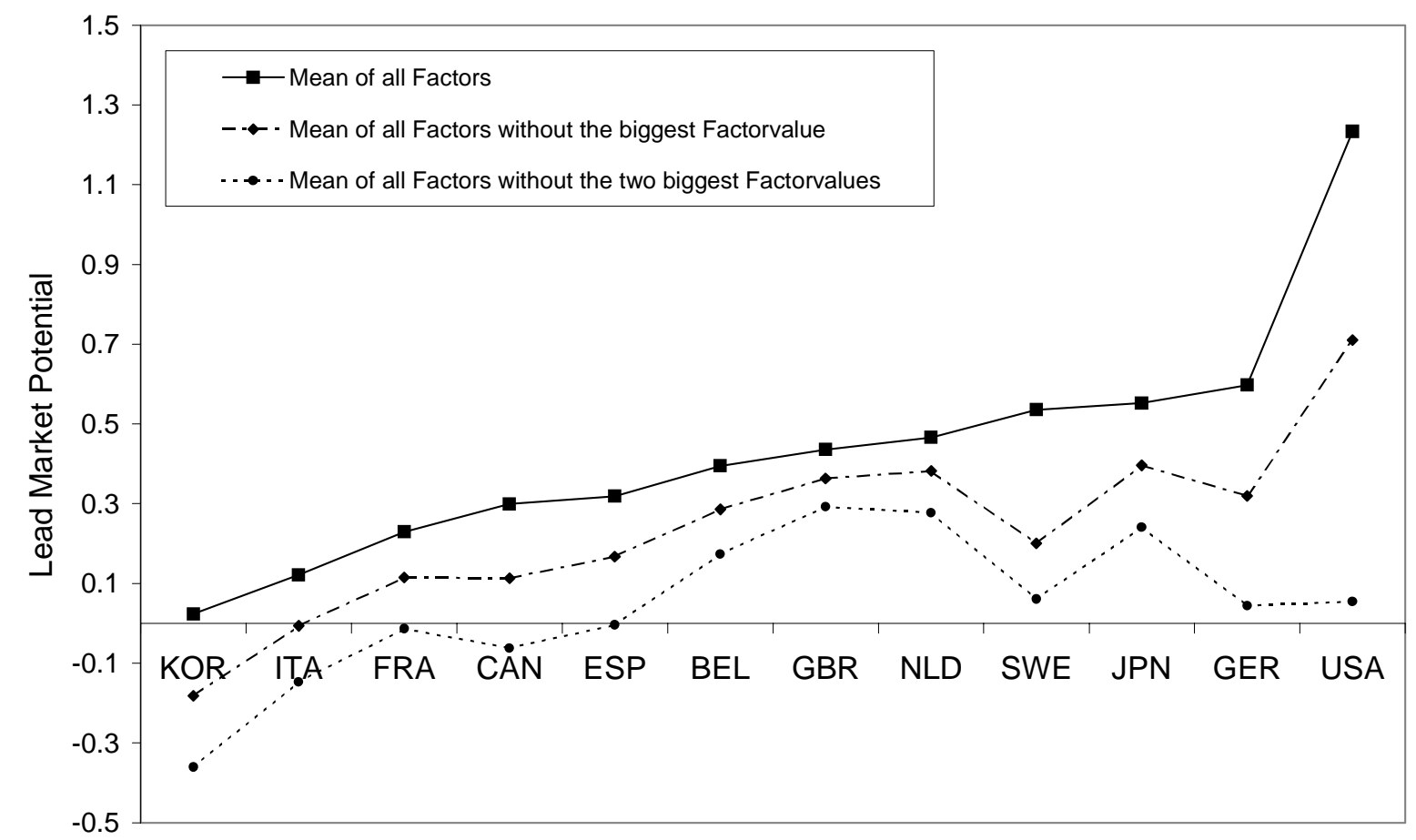

The weighting of the lead market factors is always a critical step towards aggregating location advantages into a catch all estimate of a country's attractiveness. In the process used here, the skewness of the distribution of a lead market factor across countries turns out to be the implicit weighting factor and we argue that this is actually a good one. The main components analysis lefts us with standardised values that are closer to zero for countries that are more equal to other countries and larger for countries that are more different from all other 
countries. It was argued that the lead potential is a relative variable as opposed to an absolute one. A high degree of competition doesn't make a country a lead market unless all other countries have a much lower competitive furore, keeping in mind that a country needs sway in order to overcome the preference of foreign users for domestic innovation designs. The greater the skewness of the lead market indicators, the larger the likelihood of a single country leading other countries on the adoption path. A high positive skewness reveals that one or a few countries have very large values, i.e. a large lead market advantage, while the majority of countries has lower values. This is a typical lead market situation. A negative skewness value indicates that the majority of countries cluster around the maximum value. For this lead market component, no country has a real lead market advantage.

According to the skewness interpretation, the arithmetic mean is a good aggregation method for the second step, because the mean is outlier sensitive and single large values of a factor indicating a large leverage effect of one country over all other countries.

\subsection{Results}

The exploratory test of the method shows that the results are fairly robust. In both cases, different ranking methods lead to almost the same country ranking with only small position changes. In general, it shows that data on lead market factors can be found but that this is the most time-consuming work. In the AGV case, the lead market assessment found Japan to be the most convincing potential lead market. Japan is strong in almost all lead market factors, which means that a design that is accepted in the Japanese market would be a strong competitor in the world market. The RDS project team initially argued that the best countries to introduce the technology to first would be countries with lowest coverage of maintenance infrastructure. Low coverage on the other hand is a signal for low demand for service. On the contrary, an existing high level of demand for services is an indicator of a lead market. The case study not only did not confirm the expectation of the firm's engineers but after the 
presentation of the indicators, they agreed with the lead market result. The data analysis demonstrated that their perception was biased towards particular country specific factors, neglecting several other lead market factors. This confirms that the lead market analysis, with all its shortcomings, can be an important source of information for multinational firms' innovation strategy.

\section{Conclusions for the Innovation Projects}

In the lead market analysis the lead market potential of countries are estimated in an indicator based international comparative study. The lead market potential is the power to attract users in other countries to adopt the innovation design that is preferred in the local market. This local leverage power can be used by companies in various ways. The basis for a company that develops an innovation is to respond to the preferences in the countries with the largest lead market potential when choice among technological and functional alternatives are to be made. Market analysis in the countries with a large lead market potential can further help reveal which design will be most suitable (demanded) in the lead market and which designs will not. In order to get access to this lead market knowledge, a company can use a variety of means:

- reviewing the experience of firms with prototypes tested in the potential lead markets

- traditional market research activities assessing demand preferences in the potential lead markets (e.g. conjoint measurement)

- market intelligence from research firms/consultants familiar with the market situation in the potential lead markets

- marketing activities to get early feed-back from the potential lead markets

- cooperations or strategic alliances with competitors or suppliers in the potential lead markets

- listening posts in the potential lead markets

- $\mathrm{R} \& \mathrm{D}$ activities in the potential lead markets

A company can use acquired information in a number of ways. Although the final consequence of the lead market concept is to develop and introduce the innovation design in 
the lead market, companies that lack the capacity (or willingness) to shift its development to the potential lead market have different options ranked by the degree of lead market orientation of the innovation development:

1. Develop an innovation design for the potential lead markets using lead market preferences (pro-active).

2. Develop an innovation design to fit the market demand for the home market (or a third market important for the company) including major requirements of the potential lead market (dual-use strategy).

3. Develop innovation designs for the home market but avoid technical designs which are not suited for the potential lead markets (home-market oriented lead-market strategy)

For instance, in the RDS project the developer team realised that the design first envisioned would not be suitable for the potential lead market and looked instead for technologies that were already adopted in the potential lead market. They decided then to start the RDS service first as an internet based service for small repair shops and wait to see whether the market response is positive before extending the service to the actual truck. In the AGV case the team now thinks about taking a Japanese supplier of automated guidance systems into the boat in order to gain access to the market preferences in Japan. Cooperation with an insider firm in the potential lead market offers several advantages compared to an investment in and delegation of innovation responsibility to the affiliate in the potential lead market. If a company knows little about the domestic market context of the potential lead market, cooperation partners that are insiders in the lead market are an important way to gain access to the lead market. Established domestic companies have the best information regarding the local market context, can detect new market trends early, have market experience, can evaluate market tests, and have long-term relationships with local users. This is especially important if pilot users and user-producer interaction is necessary in the market entry phase. Cooperations are less costly and therefore less risky than establishing an affiliate and acquiring a local company. 
Yet, the lead market assessment is not a save bet on what country can become a lead market. The largest lead market potential means that the probability that this country becomes the lead market is highest. This conclusion includes, first of all, that other countries can still become the lead market as well although this is not as likely. There can be errors in the estimation as well. In practice, this suggests a cautious strategy (e.g. the $3^{\text {rd }}$ option from above) when the results are rather ambiguous as well as careful examination of the results. Sensitivity analysis reveals whether the ranking is sensitive to one factor only. In the above example, the US obtains its biggest lead market potential from its size advantage. This necessitates a closer look at the economies-of-scale of the design preferred in the US compared to other designs. Furthermore, if the factor averages of the leading countries are close, the additional market research should include not only the country with the largest lead market potential but second and third ranked countries as well. Ideally, the innovation design fits market conditions in all high ranked countries. Finally, it is up to the project team to weigh up costs and lead market probability and decide whether to design an innovation and develop a market launch strategy that take the preferences of the second and third ranked countries into account.

Acknowledgements: The authors thank Dr. Michael Kokes and Mr. Titz from DaimlerChrysler AG for their support and their valuable comments. Financial support from DaimlerChrysler AG and the Foerderkreis Wissenschaft und Praxis am ZEW is gratefully acknowledged.

\section{References}

Albach, Horst, 1993, Culture and technical innovation: a cross-cultural analysis and policy recommendations, Akad. d. Wiss. zu Berlin, Working Group Culture and Technical Innovation, Berlin : de Gruyter.

Antonelli, Christiano, 1986, The international diffusion of new information technologies, Research Policy 15, 139-147.

Bartlett, Christopher A., Sumantra Ghoshal, 1990, Managing innovation in the transnational corporation, in: Bartlett, Ch., Y. Doz, G. Hedlund (eds.), Managing the global firm, London: Routledge, 215-255.

Beise, Marian, Klaus Rennings, 2003, Lead Markets of Environmental Innovations: A Framework for Innovation and Environmental Economics, ZEW Discussion Paper No 03-01, Mannheim.

Coopersmith, Jonathan, 1993, Facsimile's false starts, IEEE spectrum, February, 46-49. 
Deaton, Angus, John Muellbauer, 1980, Economics and consumer behavior, Cambridge, Mass: Cambridge University Pr.

Dekimpe, Marnik G., Philip M. Parker, Miklos Sarvary, 1998a, Staged Estimation of International Diffusion Models: An Application to Global Cellular Telephone Adoption, Technological Forecasting and Social Change 57, 105-132.

Dekimpe, Marnik G., Philip M. Parker, Miklos Sarvary, 1998b, "Globalisation": Modeling Technology adoption Timing across Countries, INSEAD working paper No. 98/69/MKT.

Dekimpe, Marnik G., Philip M. Parker, Miklos Sarvary, 2000, Multi-Market and Global Diffusion, in: V. Mahajan, E. Muller, Y. Wind (eds.), New-Product Diffusion Models, Boston et al: Kluwer, 4974.

Dosi, Giovanni, Keith Pavitt, Luc Soete, 1990, The Economics of Technical Change and International Trade, New York et al.: Harvester Wheatsheaf.

Douglas, Susan P., Yoram Wind, 1987, The Myth of Globalisation, Columbia Journal of World Business 22, Winter, 19-29.

Gatignon, Hubert, Jehoshua Elishberg, Thomas S. Robertson, 1989, Modelling Multinational Diffusion Patterns: An Efficient Methodology, Marketing Science 8 (3), 231-247.

Ganesh, Jaishankar, V. Kumar, Velavan Subramaniam, 1997, Learning Effects in Multinational Diffusion of Consumer Durables: An Exploratory Investigation, Journal of the Academy of Marketing Science 25 (3), 214-228.

Gerybadze, Alexander, Frieder Meyer-Krahmer, Guido Reger, 1997, Globales Management von Forschung und Innovation, Stuttgart: Schäffer-Poeschel.

Griliches, Zvi, 1957, Hybrid Corn: An Exploration of the Economics of Technological Change, Econometrica 25 (4), 501-522.

Hägerstrand, Torsten, 1973, Innovation Diffusion as a Spatial Process, Chicago, London: University of Chicago Press.

Hippel, Eric v., 1986, Lead users: A Source of Novel Product Concepts, Management Science 32 (7), 791-805.

Hippel, Eric v., 1988, Sources of Innovation, New York: Oxford University Press.

Jeannet, Jean-Pierre, 1986, Lead Markets: A Concept for Designing Global Business Strategies, Working Paper, IMEDE International Management Institute.

Johansson, Johny K., 2000, Global Marketing: Foreign Entry, Local Marketing, \& Global Management, Boston et al.: Irwin McGraw Hill.

Johansson, Johny K., Thomas W. Roehl, 1994, How Companies Develop Assets and Capabilities: Japan as a Leading Market, in: Schon Beechler, Allan Bird (eds.), Research in International Business and international Relations: Emerging Trends in Japanese Management, Vol. 6, Greenwich, Connecticut: JAI Press, 139-160.

Kalish, Shlomo, Vijay Mahajan, Eitan Muller, 1995, Waterfall and sprinkler new-product strategies in competitive global markets, International Journal of Research in Marketing 12, 105-119.

Kotabe, Masaaki, Kristiaan Helsen, 1998, Global Marketing Management, New York: Wiley.

Kravis, I.B., R. E. Lipsey, 1971, Price Competitiveness in World Trade, New York: National Bureau of Economic Research.

Levitt, Theodore, 1983, The Globalisation of Markets, Harvard Business Review 61 (3), 92-102.

Linder, Staffan Burenstam, 1961, An Essay on Trade and Transformation, Uppsala: Almqvist \& Wiksells. 
Maddala, G.S., Peter T. Knight, 1967, International Diffusion of Technical Change: A case study of the oxygen Steel Making Process, Economic Journal 77 (Sept.), 531-558.

Mansfield, Edwin, 1968, Industrial Research and Technological Innovation: An Econometric Analysis, New York: Norton.

Mowery, David, 1995, The Practice of Technology Policy, in: P. Stoneman (ed.), Handbook of the Economics of Innovation and Technological Change, Oxford: Blackwell, 513-557.

Nabseth, Lars, George F. Ray (eds.), 1974, The Diffusion of New Industrial Processes: An International Study, London: Cambridge University Press.

Ohmae, Kenichi, 1995, The End of the Nation State: The Rise of Regional Economies, New York: Free Press.

Porter, Michael E., 1986, Changing Patterns of International Competition, California Management Review 28 (2), 9-40.

Porter, Michael E., 1990, The Competitive Advantage of Nations, New York: Free Press.

Posner, Michael V., 1961, International Trade and Technical Change, Oxford Economic Papers 30, 323-341.

Poznanski, Kazimierz Z., 1983, International Diffusion of Steel Technologies: Time lag and the Speed of Diffusion, Technological Forecasting and Social Change 23, 305-323.

Putsis, W.P., S. Balasubramanian, E. H. Kaplan, S. Sen, 1997, Mixing Behavior in Cross-Country Diffusion, Marketing Science 16, 354-369.

Sakakibara, Mariko, Michael E. Porter, 2001, Competing at home to win abroad: Evidence from Japanese Industry, Review of Economics and Statistics 83(2), 310-322.

Swan, Philip L., 1973, The International Diffusion of an Innovation, Journal of Industrial Economics 23 (1), 61-69.

Takada, Hirokazu, Dipak Jain, 1991, Cross-National Analysis of Diffusion of Consumer Durable Goods in Pacific Rim Countries, Journal of Marketing 55, April, 48-54.

Tilton, John, E., 1971, International Diffusion of Technology: The Case of Semiconductors, Washington, D.C.: The Brookings Institution.

Utterback, James M., 1994, Mastering the Dynamics of Innovation, Boston: Harvard Business School Press.

Varian, Hal, 2001, Economics of Information Technology, mimeo.

Vernon, Raymond, 1966, International Investment and International Trade in the Product Cycle, Quarterly Review of Economics 88, May, 190-207.

Vernon, Raymond, 1979, The Product Cycle Hypothesis in a New International Environment, Oxford Bulletin of Economics and Statistics 41 (4), 255-267.

Yip, George S., 1992, Total Global Strategy: Managing for Worldwide Competitive Advantage, Englewood Cliffs: Prentice-Hall.

Yoffie, David B. (ed.), 1997, Competing in the age of digital convergence, Boston, Mass.: Harvard Business School Press.

\footnotetext{
${ }^{1}$ There are analogies to lead users suggested by v. Hippel (1986). Lead markets, however, are not simply lead users on an international level. Lead users develop innovations for their own use such as measuring devices. Lead markets are countries or regions that first adopt a specific innovation design that later becomes adopted by other countries as well, regardless of where the innovation was invented.
} 
${ }^{2}$ An innovation is often a different design of an established product (or process) and it often competes against the incumbent in the market because the older design still has its merits for some users or is cheaper. Competition between innovation designs occurs on different levels but the definition should be independent of the level of analysis. The GSM cellular telephone competes against other cellular mobile telephone standards as well as against pagers. All are different designs within the sector of mobile communications. Different designs of a nuclear reactor compete, as does nuclear energy with wind energy. Therefore, the term 'design' used here encompasses not only a technical specification but also software, a formula such as a soft drink, a technology or even a technological trajectory. For instance, the lead market for wind energy usage is Denmark (Beise and Rennings 2003). As a result, the technical development path from generator generation to generator generation, starting with small generator types in the 1980s to bigger ones in the 1990s, became globally dominant. Germany, however, failed with large generators in the 1980s and succumbed to the Danish approach.

${ }^{3}$ An additional possibility for a large multinational firm (which was not tested in our study) would be to ask market researchers of the foreign affiliates. This would mean that the R\&D department would not have to disclose information on the innovation project to experts outside the company.

${ }^{4}$ Missing data was imputed with the mean of values of all country which neutralised their impact for those countries in the final ranking. 